\title{
The Econometric Estimation of Macroeconomic Effect of Financial Development on Economic Growth in Cote d'Ivoire: A Long and Short Run Analysis, 1970-2014
}

\author{
Drama Bédi Guy Hervé ${ }^{1}$ \\ ${ }^{1}$ Département de Sciences Economiques et de Gestion Université Peleforo Gon, Cote d'Ivoire \\ Correspondence: Drama Bédi Guy Hervé; BP 1328-Korhogo-République de Côte d'Ivoire. Tel: 225-0427-8959. \\ E-mail: dramsiben.upgck@gmail.com
}

Received: February 27, 2016

Accepted: May 16, 2016

Online Published: June 25, 2016

doi:10.5539/ijef.v8n7p284

URL: http://dx.doi.org/10.5539/ijef.v8n7p284

\begin{abstract}
The aim of this article was to investigate empirically the link between financial development and economic growth in Cote d'Ivoire using time series data covering the period of 1970-2014, both in short and long run. The Error correction model and cointegration method were performed to capture the short and long run dynamics of this relationship respectively. The cointegration test result showed evidence of long-run and significant causal between financial development and economic growth in Cote d'Ivoire during the study period. Furthermore, the coefficient of the error correction term (ECT) in the short-run dynamic model was statistically insignificant with inappropriate sign and weak. Consequently, the empirical evidence suggests that countries authorities should promote domestic private credit to boost liquidity level to ensure long-term price stability and strengthen local industries production capacities.
\end{abstract}

Keywords: financial development, economic growth, financial system, Cote d'Ivoire

\section{Introduction}

For more than a century, economists have been debating the important relationship between finance and growth. The key issue centers on whether and how a well-functioning financial system could promote long-run economic growth. By the end of 1990s, many Sub-Saharan Africa (SSA) developing economies such as Cote d'Ivoire have adopted many reforms in order to liberalize financial sector. Between 1987 and 1988, the scale of the imbalances forced the state to sign an agreement with the IMF in view of implementing a financial stabilization plan from July 1989 to December 1990 with the aim of: (i) producing a positive primary balance of trade of at least 5\% in 1993, (ii) covering an increasing share of the foreign debt in order to (iii) restore the frozen relations between Côte d'Ivoire and its creditors, and finally (iv) to gradually resolve the payment arrears that had been accumulated between 1987 and 1989 (Barry, 1991). The objective of these main reforms was to accelerate privatization companies in order to reduce government spending. Also, since the end of the 1999s Côte d'Ivoire has been embroiled in a series of armed conflicts. Political instability reigned from the putsch of December 1999 to the unsuccessful coup d'état on 19 September 2002, which turned into an armed rebellion that split the country in two, interspersed with spiraling violence (Akindès, 2004; 2009). The economic recovery after Cote d'Ivoire's 2010 post-election crisis was vigorous. Following a fall in real GDP of $4.4 \%$ during the conflict in 2011, the well functioning of public institutions and economic activities has jumped nearly $11 \%$ growth in 2012. That dynamic is maintained in a range of $8 \%$ until mid- 2014 according to the latest estimates. That significant jump is possible thanks to the increasing domestic including consumption but mostly investment with a strong response to private sector. From the demand side, real economic growth was driven by a dynamic vigorous national absorption, powered the noticeable recovery of investment associated with large public programs infrastructure rehabilitation. At the same time, the effect of the decline in net exports Growth has been less felt during 2013 (Figure 1).

The last estimates show a significant continuation gain in the retail trade in 2014. Investment has peaked at $14.6 \%$ of GDP in 2013, compared to $12.1 \%$ in 2012, thanks to the realization of public investment for the rehabilitation of infrastructure and an increase of private investment to expand mining and oil sectors capacity. Indeed, the level of remarkable public investment spending is specific to this episode of recovery after the 
conflict. The industrial sector recorded strong growth of $8.8 \%$ in 2013, following a decline of $1.4 \%$ the previous year. The industrial production experienced more modest progression $4.7 \%$ over the year to the mid-2014. The increase in private consumption was supported by job creation in the formal private sector and the public sector;and a $17.4 \%$ increase in real incomes of coffee and cocoa planters also boosted household demand. With normalization of the political situation, and primer an economic recovery underway, hiring in the private sector (4.8\% increase in jobs) and public sector $(+4.5 \%)$, resulting in overall increase in formal employment by $5 \%$ in 2013. Total public spending remained unchanged at $22.1 \%$ of GDP in 2013 . However, we note a change in the composition of public expenditure, with strong increased of capital expenditures and a decrease in expenses. The Investment expenses increased by compared to 2013 reach $6.1 \%$ of GDP (against $4.5 \%$ in 2012), due to public works and other infrastructure improvement projects. However, investment spending still below planned levels (7.2\% of GDP), reflecting delays and some weaknesses in the implementation of the public investment program.

Although the recent spectacular growth, this paper seeks to find response to this question: This fast growth will be consolidated in long run? The rest of this study is organized as follows: Section 2 deals with literature review. Section 3 outlines the model specification and estimation methods then we also describe the source of our selected data and measurement. Section 4 highlights the econometric analysis and interpretation of the empirical results both in short and long run. It is followed by the summary, policy discussions and conclusions, respectively in Section 5 .

\section{Literature and Empirical Framework}

Several theoretical studies have attempted to substantiate how financial development can stimulate economic growth. (Schumpeter, 1912) argued that the well functioning of banks stimulates technological innovation and accelerate growth. (Levine, 2005) emphasizes that financial intermediaries through five functions they play, stimulate growth through capital accumulation and factor productivity. These five functions cover the production of information on the projects and the allocation of resources to the most profitable projects; investment monitoring and control on business management; facilitation of financial and commercial transactions, and improving risk management; the mobilization of savings and; the facilitation of trade in goods and services.

Many theoretical and empirical studies have sought for decades to explain the relationship between financial development and economic growth. Indeed, economists have long disagreed on the role of the financial sector in economic growth. Most of them, including winners of Nobel Prize in Economics including Robert Lucas (1988), had rejected the idea of a major role of financial development on economic growth. Thanks to several research, other economists whose (Goldsmith, 1969), blew open the idea that one can ignore the link between financial development and growth without substantially impeding our understanding of the process of economic growth (Levine, 2005). However, different views, even contradictory, are born from the interpretation of the results of this work. Some argue that financial development is essential to growth, while others say it is economic growth that determines the level of financial development of a country. Moreover, it should be noted that although most studies find evidence of a positive correlation between financial development and growth, a number of researchers provide evidence contrary to this assertion. In this section, we first review the results corroborating a positive relationship between finance and growth and then we will examine the controversy surrounding this literature. Including the empirical literature on the relationship between financial development and economic growth has boomed since the work of (King \& Levine, 1993). Although (Levine, 2005) attributes the first study establishing the empirical link between finance and growth to (Goldsmith, 1969), (King \& Levine, 1993a) has validated several endogenous growth models such as (Greenwood \& Jovanovic, 1990), (Bencivenga \& Smith, 1991) and (St. Paul, 1992) in particular.

Ross Levine in an article entitled Financial Development and Economic Growth: Views and Agenda 1997 adopts a functional approach "to try to explain theoretically, by what mechanism financial system affects economic growth King and Levine (1993a) were the first authors to make an empirical analysis. They took a sample of 77 countries over a period from 1960 to 1989. They regressed the average growth of gross domestic product (GDP) per capita or the average growth of Total Factor Productivity (TFP) on financial development and control variables. The control variables include the initial income per capita, education, political stability and economic policy indicators. King and Levine show substantial and significant correlation between productivity growth and the measures listed above. Similar results corroborate a positive relationship between financial development and economic growth have been obtained by other researchers as (Rajan \& Zingales, 1998), (Demirgucs-Kunt \& Maksimovic 1996a; 1996b). (Rajan \& Zingales, 1998) find that by reducing the financing cost for those industries which rely more on external finance, more developed financial systems could promote faster industrial growth and therefore faster economic growth while (Demirgucs-Kunt \& Maksmovic, 1996a; 1996b) also argue that firms with access to well-developed financial markets grow comparatively faster. 
After the work of King and Levine (1993a) inspired the assertion of (Schumpeter 1912), several studies have examine the extent of the relationship between financial sector and growth by questioning (Schumpeter, 1912) empirical results in other words, the direction of causality between financial development and economic growth. In the opinion of some of these authors, financial development is not prior to economic growth, but rather the opposite. Among those supporting the controversy include the contributions of (Arestis \& Demetriades, 1996) which show that when the correlation between financial development index has taken the average and its initial level is strong, financial development predicts more economic growth. These arguments are at the origin of the ambiguity on the direction of causality in the relationship between finance and growth. Furthermore, most studies on the analysis of the link between finance and economic growth measures were focused on the banking system thus obscuring part of financial development namely that linked to the rise of the financial markets. Thus, to better reflect the financial development in the country, some studies incorporate indicators to measure the size and liquidity of financial markets. The work of (Levine \& Zervos, 1998) and (Beck \& Levine, 2002) provide evidence that the development of financial markets is an indicator that allows a better understanding of the economic growth process.

\section{Model Specification, Investigation Methodology Applied Data Sources and Measurement}

\subsection{Specification of Our Model}

In this paper, we use the econometric performed by Levin (1997) to investigate the macroeconomic effect of Financial Development on Economic Growth in Cote d'Ivoire both in long and short run analysis spanning the period 1970 to 2014. Therefore our econometric model is expressed as follow:

Where:

$$
R G D P g_{t}=\beta_{0}+\beta_{1} F D L+\beta_{2} M P R+\beta_{3} T O P+\beta_{4} I N F+\beta_{5} E X R+\varepsilon_{t}
$$

$\mathrm{RGDPg}=$ Real gross domestic product growth rate;

$\mathrm{FDL}=$ Ratio of total money supply to GDP as financial liquidity.

MPR= Monetary policy rate proxy by interest rate;

TOT $=$ Trade openness as ratio of total trade to GDP

$\mathrm{INF}=$ Inflation rate

EXR= Exchange rate of CFA vis-à-vis EURO;

$\beta_{0}=$ Intercept or constant

We expected to have the following sign of our coefficients as follow: $\beta_{1}, \beta_{3}>0, \beta_{2}, \beta_{4}, \beta_{5}<0$. It attempt to find out whether the independent variables have significant influence on dependent variable or not, that is $\beta_{i}$ is significantly equal to zero or not. Mathematically, this hypothesis can be written as:

$H_{0}: \beta_{i}=0$

$H_{1}: \beta_{i} \neq 0$

\subsection{Investigation Methodology Applied}

In this subsection, we first need ensure that all variables are stationary to avoid the spurious regression problem associated with unit roots. So the unit root tests on relevant economic variables are performed in order to determine time series characteristics. This study uses the Augmented (Dickey-Fuller, 1979) and (Phillip-Peron, 1988) unit root tests for presence of unit root. Second, the long run relationship between macro-variables is conducting using (Johansen, 1988) and (Juseluis, 1990) cointegration test. Finally, the Error Correction Model (ECM) is running because it produces good forecasts in short run Lesage, (1990).

\subsection{Data Sources}

Our data sources are selected from the World Development Indicators published (2015) by the World Bank covering the whole period 1970 to 2014 . Where RGDP is Real gross domestic product growth rate, FDL represents the ratio of total money supply to GDP as financial liquidity, MPR is monetary policy rate proxy by interest rate, TOT is trade openness ratio of total trade to GDP, EXR is exchange rate of CFA vis-à-vis EURO and the consumer price index as a proxy of inflation rate is depicted by INF.

\section{Empirical Results and Interpretations}

\subsection{Empirical Results}

A descriptive analysis of the data which are presented in table 1 was conducted. Usually normally distributed 
variables give better results than variables which are not normally distributed. The table presents the normality test of the variables. It was found that some of the data are not normally distributed as shown in the table 1 below. All variables exhibit a positive mean return excepted real gross domestic product growth rate $(R G D P)$ because higher fluctuation during the study period. Also the sum squared deviation row represents the net change over the sample period. In terms of skewness, financial liquidity $(F D L)$, Interest rate $(M P R)$ and Real Exchange rate $(E X R)$ have return distribution that are positively skewed. $R G D P$ and trade openness (TOP) exhibit a negative skewness which implies that they have a long left tail. All the variables are relatively normally distributed as indicated by the $\mathrm{p}$ values of Jarque Bera statistic.

Table 1. Summary of the descriptive statistic of the data

\begin{tabular}{|c|c|c|c|c|c|c|}
\hline & RGDP & FDL & MPR & TOP & INF & EXR \\
\hline Mean & -1.214872 & 28.77464 & 10.59899 & 74.01475 & 6.430499 & 121.6473 \\
\hline Median & -0.692174 & 27.91525 & 9.939500 & 74.51004 & 4.313954 & 108.8841 \\
\hline Maximum & 7.850099 & 40.45515 & 50.90934 & 94.90811 & 46.38607 & 166.7861 \\
\hline Minimum & -14.86414 & 21.67547 & -26.73006 & 10.27535 & -4.523274 & 90.89341 \\
\hline Std. Dev. & 4.338930 & 4.896544 & 14.85355 & 14.58837 & 9.572000 & 26.87915 \\
\hline Skewness & -0.420368 & 1.012972 & 0.992931 & -1.743785 & 2.255060 & 0.967099 \\
\hline Kurtosis & 3.825073 & 3.675131 & 4.931248 & 9.180690 & 8.736234 & 2.227422 \\
\hline Jarque-Bera & 2.601717 & 8.550476 & 14.38757 & 94.43266 & 99.83545 & 8.133745 \\
\hline Probability & 0.272298 & 0.013909 & 0.000751 & 0.000000 & 0.000000 & 0.017131 \\
\hline Sum & -54.66926 & 1294.859 & 476.9545 & 3330.664 & 289.3725 & 5474.127 \\
\hline Sum Sq. Dev. & 828.3579 & 1054.950 & 9707.634 & 9364.101 & 4031.420 & 31789.51 \\
\hline Observations & 45 & 45 & 45 & 45 & 45 & 45 \\
\hline
\end{tabular}

Source: Own calculation using data from regression analysis.

Second, we perform unit root test to verify the stationarity of our variables by utilizing the univariate Augmented Dickey-Fuller $(A D F)$ and Phillip-Peron (PP) unit root tests procedure. The results are reported in Table 2 bellow. The overall test shows that we fail to reject the stationary null hypothesis base on $A D F$ and $P P$ test at level excluded real gross domestic product growth rate $(R G D P)$. Thus, according the empirical foundation, we conclude that all variables follow the $I(1)$ process. Beyond testing for the unit root, there is a need to establish whether the non-stationary variables are cointegrated so we follow the method developed by Johansen (1988) and Juselius (1990) to test for the presence of equilibrium relationship between economic variables. The concept of cointegration implies that, there is a long run relationship between two or more non-stationary variables. Table 3 displays the results.

Table 2. Univariate unit root tests

\begin{tabular}{|c|c|c|c|c|}
\hline \multirow{2}{*}{$\begin{array}{c}\text { Test variables } \\
\text { Level }\end{array}$} & \multicolumn{2}{|c|}{ ADF Statistics } & \multicolumn{2}{|c|}{ PP Statistics } \\
\hline & Trend & No Trend & Trend & No Trend \\
\hline$L n R G D P$ & $-5.205^{* * *}$ & -1.218 & $5.211^{* * *}$ & $-2.143^{* *}$ \\
\hline$F D L$ & -0.918 & 0.834 & -0.784 & 0.934 \\
\hline$M P R$ & -0.737 & 0.848 & -0.586 & 0.939 \\
\hline$T O T$ & $-2,047$ & 0.410 & -2.082 & 0.388 \\
\hline$I N F$ & $-2,523$ & 4.715 & $-2,068$ & 3.900 \\
\hline \multirow[t]{2}{*}{$E X R$} & $-2,273$ & -0.469 & -2.387 & -0.438 \\
\hline & & First Differ & & \\
\hline$\triangle L n R G D P$ & & $-9.708 * * *$ & $-20.824 * * *$ & \\
\hline$\triangle F D L$ & $-6.684 * * *$ & $-6.263^{* * *}$ & $-6.682 * * *$ & $-6.243 * * *$ \\
\hline$\triangle M P R$ & $-6,657 * * *$ & $-6.182 * * *$ & $-6.658 * * *$ & $-6.168 * * *$ \\
\hline$\triangle T O T$ & $-5.294 * * *$ & $-5.287 * * *$ & $-5.277 * * *$ & $-5.289 * * *$ \\
\hline$\triangle I N F$ & $-4.219^{* *}$ & $-2.793 * * *$ & $-4.219 * * *$ & $-2.727 * *$ \\
\hline$\triangle E X R$ & $-5.743 * * *$ & $-5.941 * * *$ & $-5.757 * * *$ & $-5.966 * * *$ \\
\hline
\end{tabular}

Source: Own calculation using data from regression analysis.

The $\Delta$ denotes first-difference derivation. The asterisks $*, * *$, and $* * *$ denote statistical significance at $1 \%, 5 \%$, and $10 \%$ levels, respectively. McKinnon (1980) critical values are used for rejection of the null unit root. 
Fourth, after getting the long-run cointegration relationship using (Johansen, 1988) and (Juselius, 1990) procedure, the error-correction model (ECM) can be expressed and estimated with a more appropriate dynamic simple. Thus, an error correction term lagging one period error-correction term $\left(E C T_{t-1}\right)$ is carry out to capture the long run relationship by attempt to correct deviations from the long run equilibrium path. Its coefficient can be interpreted as the speed of adjustment or the amount of disequilibrium transmitted each period to amount of real gross domestic product growth rate $(R G D P)$ with appropriate lag order $k=6$ for the periods 1970-2014.

\subsection{Interpretation of Empirical Results}

In so doing, we performed univariate augmented Dickey-Fuller (ADF) and Phillips-Peron (PP) unit root tests for each variable that enters the multivariate model. The results over the period 1970-2014 reported in Table 1 fail to reject the null hypothesis at level based on the tests mentioned above. But the overall tests shows that all the variables are stationary at first difference and treated as integrated $I(1)$ process according the literature while RGDP is stationary at levels.

Turning to the long-run analysis, we performed the cointegration test using (Johansen, 1988) and (Juselius, $1990)$. The result demonstrated that real gross domestic product growth $\operatorname{rate}(R G D P)$ financial liquidity $(F D L)$, Interest rate $(M P R)$, trade openness $(T O P)$, inflation (INF) and Real Exchange rate $(E X R)$ are cointegrated at the $5 \%$ level of significance. Both the maximum eigenvalue $\left(\lambda_{\max }\right)$ and the trace statistics $\left(\lambda_{\text {race }}\right)$ tests identify a unique statistically significance vector with $\left(\lambda_{\max }=66,921 ; \lambda_{\text {race }}=143,048\right)$ see Table 3 . Second, the long run estimated result for the multiple parameters regression specified to capture the effect of financial development on economic growth in Cote d'Ivoire between 1970 and 2014 presented in Table 4 reveals that financial development as a measure financial liquidity (FDL) in economy proxy by ratio of total money supply to gross domestic product, Monetary policy rate proxy by interest rate(MPR), inflation rate (INF) and exchange rate (EXR) have positive and inelastic effect on economic growth proxy as changes in real gross domestic product (RGDP) Cote d'Ivoire during the study period. But trade openness (TOP) a measure of economic integration/ globalization, inflation rate (INF) and exchange rate (EXR) show negative and positive sign respectively effect during the same period. These effects are conformed to our theoretical expectation excluding inflation rate and real exchange rate. The results show that all estimated parameters are statistically significant at the standard level $1 \%, 5 \%$ and $10 \%$ excluding trade openness. The obtained $R^{2}$ in the model of 0.483 implies that the explanatory variables included in the model explain more than 48 percent of all variations in growth performance. The Probability of rejecting the model specification given by Prob (F-statistics) of 0.000065 reflects that the model is well specified. In case the model is adjusted the $R^{2}$ will be reduced to 41.7 percent, which is still preferable in explaining the model variation and thus according to the result we can accept the null hypothesis that the growth performance of the country follow the long run process. We check the stability of our model by computed the CUSUM and CUSUMQ square (Brown \& Durbin, 1975). The cumulative sum of residuals plot is reported in figure 1. These show that the general equilibrium of our model is quite stable in long run.

Table 3. Johansen cointegration test (sample 1970-2014)

\begin{tabular}{ccccccc}
\hline $\begin{array}{c}\text { Null } \\
\text { Hypothesis }\end{array}$ & $\begin{array}{c}\text { Alternative } \\
\text { Hypothesis }\end{array}$ & Eigen Value & $\begin{array}{c}\text { LR/Trace } \\
\text { Statistics }\left(\boldsymbol{\lambda}_{\text {trace }}\right)\end{array}$ & $\begin{array}{c}\text { Critical value } \\
\mathbf{5 \%} \text { level }(\boldsymbol{C} . \boldsymbol{V} \text {. })\end{array}$ & $\begin{array}{c}\text { Maxi-Eigen } \\
\text { Statistics }\left(\boldsymbol{\lambda}_{\max }\right)\end{array}$ & $\begin{array}{c}\text { Critical value } \\
\mathbf{5 \%} \text { level }(\boldsymbol{C} . \boldsymbol{V} \text {. })\end{array}$ \\
\hline $\mathrm{r}=0$ & $\mathrm{r}=1$ & 0.785 & 143.048 & 107.346 & 66.29160 & 43.419 \\
$\mathrm{r} \leqslant 1$ & $\mathrm{r}=2$ & 0.606 & 76.756 & 79.341 & 40.15234 & 37.163 \\
$\mathrm{r} \leqslant 2$ & $\mathrm{r}=3$ & 0.373 & 36.604 & 55.245 & 20.08335 & 20.815 \\
$\mathrm{r} \leqslant 3$ & $\mathrm{r}=4$ & 0.207 & 16.521 & 35.010 & 10.00170 & 0.903 \\
$\mathrm{r} \leqslant 4$ & $\mathrm{r}=5$ & 0.106 & 6.519 & 18.379 & 4.840873 & 0.913 \\
$\mathrm{r} \leqslant 5$ & $\mathrm{r}=6$ & 0.038 & 1.678 & 3.841 & 1.678516 & 0.195 \\
\hline
\end{tabular}

Source: Own calculation using data from regression analysis.

Table 4. Estimated regression model in long run

\begin{tabular}{lcccc}
\hline \multicolumn{5}{c}{ Dependent Variable: RGDP } \\
\hline Method: Least Squares & & & & \\
Sample: $1970-2014$ & & & T-Statistic & Probability \\
\hline Variables & Coefficients & Std Error & 1.213 & 0.232 \\
$\boldsymbol{C}$ & 4.903 & 4.041 & -3.262 & 0.000 \\
\hline FDL & $0.255^{* * *}$ & 0.117 & & \\
\hline
\end{tabular}




\begin{tabular}{lcccc}
\hline MPR & $-0.013^{* * *}$ & 0.052 & 4.819 & 0.723 \\
TOP & -0.354 & 0.038 & -0.356 & 0.0001 \\
$\boldsymbol{I N F}$ & $0.045^{* * *}$ & 0.078 & -4.511 & 0.032 \\
$\boldsymbol{E X R}$ & $0.045^{* * *}$ & 0.020 & 2.222 & 0.232 \\
\hline
\end{tabular}

Source: Computation from data used in Regression Analysis.

Note: $R^{2}=0.483$ imply that the model is good fit. F-test result indicates the overall significance of the model. The asterisks ***, ** and

$*$ implies statistically significant at $1 \%, 5 \%$ and at $10 \%$ level respectively.
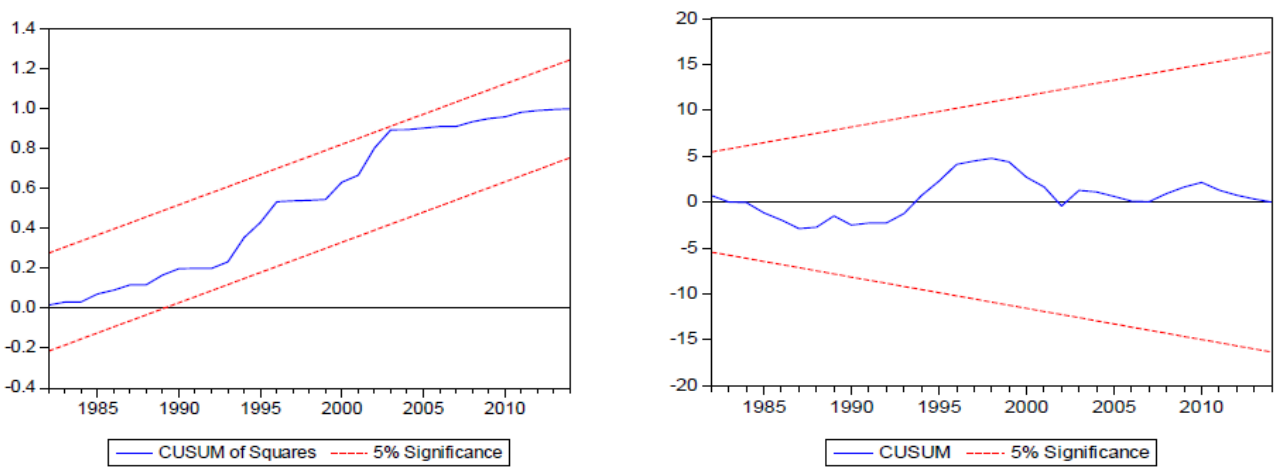

Figure 1. Plot of cumulative sum of squares of recursive residuals for CUSUM 5\% significance and CUSUM of squares $5 \%$ significance

Third, we analyze the short run dynamic effect by performing the error-correction model (ECM) and can be expressed and estimated with a more appropriate simple dynamic representation. Results on Table 5 represents the estimation of the over parameterized model as well. As shown in the general model, most of the insignificant variables whose T-Statistics is less than 2 , have been eliminated without losing valuable details and will not appear in the preferred model. The only significant variables (whose T-Statistic is greater than or equal to 2) will be appearing in the preferred model as it is shown in Table 5. Following the dropping out of insignificant variables in the general model without losing valuable information; the short-run dynamics of real gross domestic product (RGDP) function is analyzed by computing an error-correction model (ECM) with lags length $(\mathrm{k}=6)$ and report a significance F-test statistics which implying that there is an improvement in the overall significance of the model. The result also displays an incorrect sign (positive) not meaningful and relatively higher $\left(E C T_{t-1}\right)$ coefficient $(0.053380)$. This implies that macroeconomic effect of financial development on economic growth in Cote d'Ivoire is weak in short run.

Table 5. Estimated regression model in short run

\begin{tabular}{ccccc}
\hline \multicolumn{5}{c}{ Dependent Variable: RGDP } \\
\hline Method: Least Squares & Coefficients & Std Error & T-Statistic & Probability \\
Variables & 11.24178 & 4.623222 & $2.431589 * * *$ & 0.0511 \\
C & -1.881470 & 0.833314 & $-2.257817 * * *$ & 0.0647 \\
DFDL(-5) & -0.298642 & 0.148241 & $-2.014565^{* * *}$ & 0.0906 \\
DMPR(-1) & -0.310254 & 0.118883 & $-2.609740 * * *$ & 0.0401 \\
DMPR(-6) & 0.133239 & 0.063146 & $2.110008 * * *$ & 0.0794 \\
DTOP(-6) & 0.398080 & 0.163651 & $2.432494 * * *$ & 0.0510 \\
DINF(-1) & -0.233110 & 0.081597 & $-2.856830 * * *$ & 0.0289 \\
DEXR(-1) & -0.120801 & 0.058353 & $-2.070185 * * *$ & 0.0839 \\
DEXR(-4) & $\mathbf{0 . 0 5 3 3 8 0}$ & 0.021285 & $2.507893 * * *$ & 0.0460 \\
ECT(-1) & & & & \\
\hline
\end{tabular}

Source: Computation from data used in Regression Analysis.

Note. $R^{2}=0.944$ imply that the model is good fit. F-test result indicates the overall significance of the model. The asterisks $* * *, * *$ and * implies statistically significant at $1 \%, 5 \%$ and at $10 \%$ level respectively. 


\section{Conclusion}

The main objective of this paper was to analyze the effect of financial development on economic growth in Cote d'Ivoire using the recently time series data covering the period of 1970-2014. Unit root test was conducted to test the stationary of data and cointegration test was performed to test for the existence of the long-run relationships of the variables. In the same way, our model was generated from overparameterized, based on statistic rather economic by the error correction model. Finally, according the importance of the stability in the regression analysis of the model, we run the stability test to check whether our regression was stable at the conventional significance level. The Johansen (1988) and Juselius (1990) test confirm the presence of a long run cointegrating relationship among the variables used for this study. The estimated model results revealed that economic growth is inelastic of financial development and other macroeconomic indicators in Cote d'Ivoire in long run. In addition, the study also shows that financial liquidity and interest rate have long run significant impact and seem to be the main determinant of the country's growth during the study period. On the basis of our empirical output, the study suggests that countries authorities should promote domestic private credit to boost liquidity level and expand the financial sector base in the domestic economy to ensure long-term price stability and promote output. Therefore, this study concludes that financial development has insignificant and weak effect on the Cote d'Ivoire's economy in short run.

\section{References}

Abu-Bader, S., \& Abu-Qarn, A. M. (2008). Financial development and economic growth: Empirical evidence from MENA countries. Review of Development Economics, (12), 803-817. http://dx.doi.org/10.1111/j.1467-9361.2008.00427.x

Agbetsiafa, D. (2004). The finance growth nexus: Evidence from Sub-Saharan Africa. Savings and Development, $38,271-288$.

Agbetsiafa, D. K. (2003). The finance growth nexus: Evidence from sub-saharan Africa. International Advances in Economic Research, 9, 172-189. http://dx.doi.org/10.1007/BF02295728

Akinboade, O. A. (1998). Financial development and economic growth in Botswana: A test for causality. Savings and Development, 22, 331-348.

Akindès, F. (2004). The roots of the military-political crises in Côte d'Ivoire. Sweden, Nordiska Afrikainstitutet.

Akindès, F. (2009). Côte d'Ivoire since 1993: The Risky Reinvention of a Nation. In A. M. Raufu, \& L. Whitfield (Eds.), Turning Points in African Democracy (pp. 31-49). London, James Currey.

Al-Yousif, Y. K. (2002). Financial development and economic growth: Another look at the evidence from developing countries. Review of Financial Economics, 11, 131-150. http://dx.doi.org/10.1016/S1058-3300(02)00039-3

Amonoo, E., Acquah, P. K., \& Asmah, E. E. (2003). The Impact of Interest Rates on Demand for Credit and Loan Repayment by the Poor and SMEs in Ghana. IFLIP Research Paper 03 10, International Labor Organization.

Andersen, T. B., \& Tarp, F. (2003). Financial Liberalization, Financial Development and Economic Growth in LDCs. Journal of International Development, 15(2), 189-209. http://dx.doi.org/10.1002/jid.971

Arestis, P., \& Demetriades, P. (1997). Financial Development and Economic Growth: Assessing the Evidence. Economic Journal, 107, 783-799. http://dx.doi.org/10.1111/j.1468-0297.1997.tb00043.x

Arestis, P., \& Caner, A. (2004). Financial Liberalization and Poverty: Channels of Influence. Levy Economics Institute Working Paper no. 411. http://dx.doi.org/10.2139/ssrn.569663

Baliamoune-Lutz. (2008). Financial development and income. International Advances in Economic Research, 14, 422-432. http://dx.doi.org/10.1007/s11294-008-9176-5

Bencivenga, R., \& Smith, B. (1991). Financial Intermediation and Endogenous Growth. Review of Economic Studies, 58, 195-209. http://dx.doi.org/10.2307/2297964

Besley, T., \& Burgess, R. (2003). Halving Global Poverty. Journal of Economic Perspectives, 17(3), 3-22. http://dx.doi.org/10.1257/089533003769204335

Bhattacharya, P., \& Sivasubramanian, M. (2003). Financial development and economic growth in India: 1970-1971 to 1998-1999. Applied Financial Economics, 13, 925-929. http://dx.doi.org/10.1080/0960310032000129590 
Blundell, R., \& Bond, S. (1998). Initial conditions and moment restrictions in dynamic panel data models. Journal of Econometrics, 87(1), 115-143. http://dx.doi.org/10.1016/S0304-4076(98)00009-8

Bojanic, A. N. (2012). The impact of financial development and trade on the economic rowth of Bolivia. Journal of Applied Economics, XV(1), 51-70. http://dx.doi.org/10.1016/S1514-0326(12)60003-8

Campos, N. F., Karanasos, M. G., \& Tan, B. (2012). Two to tangle: Financial development, political instability and economic growth in Argentina. Journal of Banking and Finance, 36, 290-304. http://dx.doi.org/10.1016/j.jbankfin.2011.07.011

Caporale, G. M., \& Pittis, N. (1995). Causality inference in bivariate and trivariate systems: Some more results. Discussion paper No. DP15 - 95, Centre for Economic Forecasting, London Business School.

Darrat, A. F. (1999). Are financial deepening and economic growth casually related? Another look at the evidence. International Economic Journal, 13(1), 19-35.

Dasgupta, D., \& Dilip, R. (2000). What Factors Appear to Drive Capital Flows to Developing Countries? And How does Official Lending Respond? Policy Research Working Paper 2392, The World Bank.

De Gregorio, J., \& Guidotti, P. E. (1995). Financial Development and Economic Growth. World Development, 23(3), 433-448. http://dx.doi.org/10.1016/0305-750X(94)00132-I

Demetriades, P. O., \& Hussein, K. (1996). Does financial development cause economic growth? Journal of development Economics, 51, 387-411. http://dx.doi.org/10.1016/S0304-3878(96)00421-X

Demirguc, P. D., \& Maksimovic, V. (1996). Financial constraints, use of funds and firm growth: An international comparison. Working paper no 1671, World bank.

Dickey, D. A., \& Thornton, D. A. (1991). A Primer on cointegration with an Application to Money and Income. Great Britain: Macmillan press.

Dickey, F. (1979). Distribution of the Estimators for Autoregressive time series with Unit Roots. Journal of American Statistical Associations.

Dickey. (1991). A Primer on Cointegration with an Application to Money and Income. Review, Federal Reserve Bank of St. Louis, 73, 58-78.

Emerging Stock Market Fact Book. (2000). Standard and Poor 's, A Division of McGraw-Hill Companies. New York USA.

Goldsmith, R. W. (1969). Financial structure and development. New Haven, CT: Yale University Press.

Greenwood, B. J. (1990). The Journal of Political Economy, 98(5), 1076-1107. http://dx.doi.org/10.1086/261720

InternationalLabor Organization. (n. d.). Savings and Lending for the SMEs and the Poor. IFLIP Research Paper 03-7.

Johansen, S., \& Juselius, K. (1990). Maximum Likelihood Estimation and Inferences on Co-integration with Application to the Demand for Money. Oxford Bull. Econ. Stat., 52, 169-210. http://dx.doi.org/10.1111/j.1468-0084.1990.mp52002003.x

King, R. G., \& Levine, R. (1993). Financial and growth: Schumpeter might be right. The Quarterly Journal of Monetary Economics, XXXII, 513-542. http://dx.doi.org/10.1016/0304-3932(93)90028-E

Levine, R. (2003). Stock markets liquidity and economic growth: Theory and evidence. In L. Paganetto, \& E. S. Phelps (Eds.), Finance, Research, Education and Growth. New York: Palgrave Macmillan. http://dx.doi.org/10.1057/9781403920232_1

Levine, R. (2005). Finance and Growth: Theory and Evidence. In P. Aghion, \& S. Durlauf (Eds.), Handbook of Economic Growth (Vol. 1, Part A, pp. 865-934). The Netherlands: Elsevier Science.

Levine, R., \& Sara, Z. (1998). Stock markets, banks, and economic growth. American Economic Review, 88(3), 537-558.

Levine, R., Loayza, N., \& Beck, T. (2000). Financial Intermediation and Growth: Causality and Causes. Journal of Monetary Economics, 46, 31-77. http://dx.doi.org/10.1016/S0304-3932(00)00017-9

Lucas, R. E. (1988). On the Mechanics of Economic Development. Journal of Monetary Economics, 22, 3-42. http://dx.doi.org/10.1016/0304-3932(88)90168-7

Quartey, P. (2005). Financial Sector Development, Savings Mobilization and Poverty Reduction in Ghana. UNU-WIDER Research Paper No.2005/71, Helsinki: UNU World Institute for Development Economics 
Research.

Raghuram, G. R., \& Luigi, Z. (1998). The American Economic Review, 88(3), 559-586.

Robinson, J. (1952). The civilizations of the general theory: The rate of interest and other essay. London. Macmillan Press.

Rousseau, P. L., \& Wachtel, P. (2005). Economic Growth and Financial Depth: Is the Relationship Extinct Already? Discussion Paper No. 2005/10, Helsinki: UNU World Institute for Development Economics Research.

Saint-Paul, G. (1992). Productivity Growth and the Structure of the Business Cycle. CEPR Discussion Papers 709.

Schumpeter, J. A. (1912). The Theory of Economic Development: An Inquiry into Profits, Capital, Credit, Interest and the Business Cycle. Translated from the German by Redvers Opie, New Brunswick (U.S.A) and London (U.K.): Transaction Publishers.

Shaw, E. S. (1973). Financial Deepening in Economic Development. New York: Oxford University Press.

Soyibo, A. (1995). Financial Linkage and Development in Sub-Saharan African: A study of the Informal Financial Sector in Nigeria. Working Paper 88, Overseas Development Institute, London.

Soyibo, A. (1996). Financial Linkage and Development in Sub-Saharan African: The Role of Formal Financial Institutions in Nigeria. Working Paper 88, Overseas Development Institute, London.

Umutlu, M., Akdeniz, L., \& Altay-Salih, A. (2010). The degree of financial liberalization and aggregated stock-return volatility in emerging markets. Journal of Banking and Finance, 34, 509-521. http://dx.doi.org/10.1016/j.jbankfin.2009.08.010

Wacziarg, R., \& Karen, W. (2008). Trade liberalization and growth: New evidence. World Bank Economic Review, 22, 187-231. http://dx.doi.org/10.1093/wber/lhn007

Windmeijer, F. (2005). A finite sample correction for the variance of linear efficient two-step GMM estimators. Journal of Econometrics, 126, 25-51. http://dx.doi.org/10.1016/j.jeconom.2004.02.005

\section{Appendix}

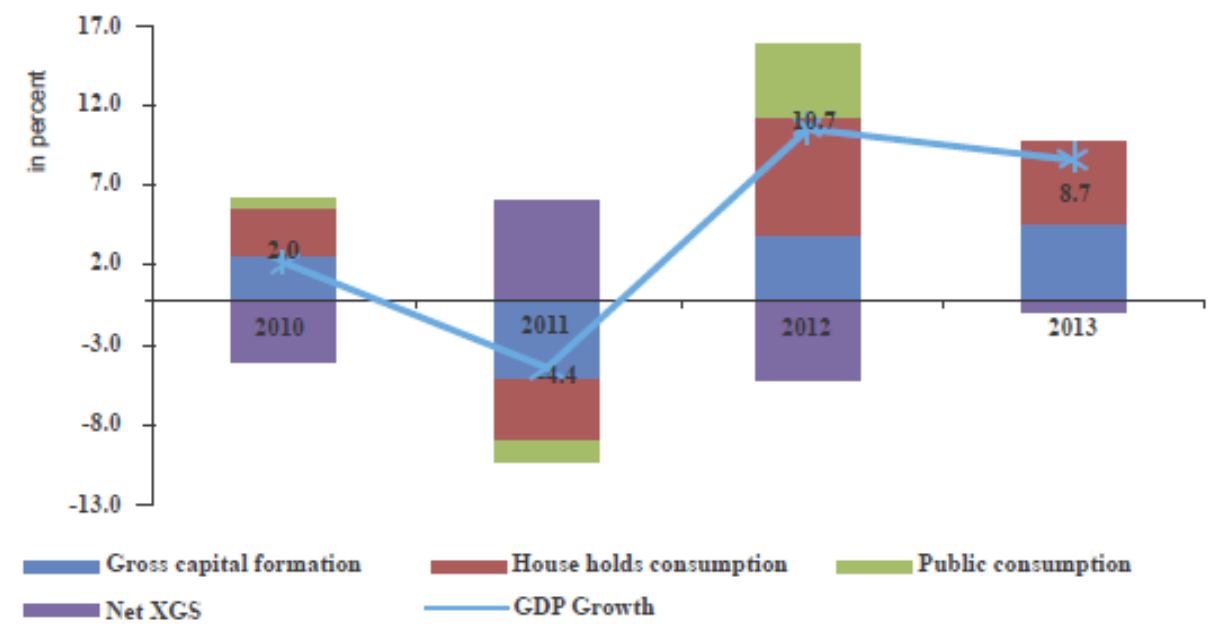

Appendix 1. Growth categories of real expenditure, 2010-2013

Source: Ministry of Economic and Finance of Cote d'Ivoire. 


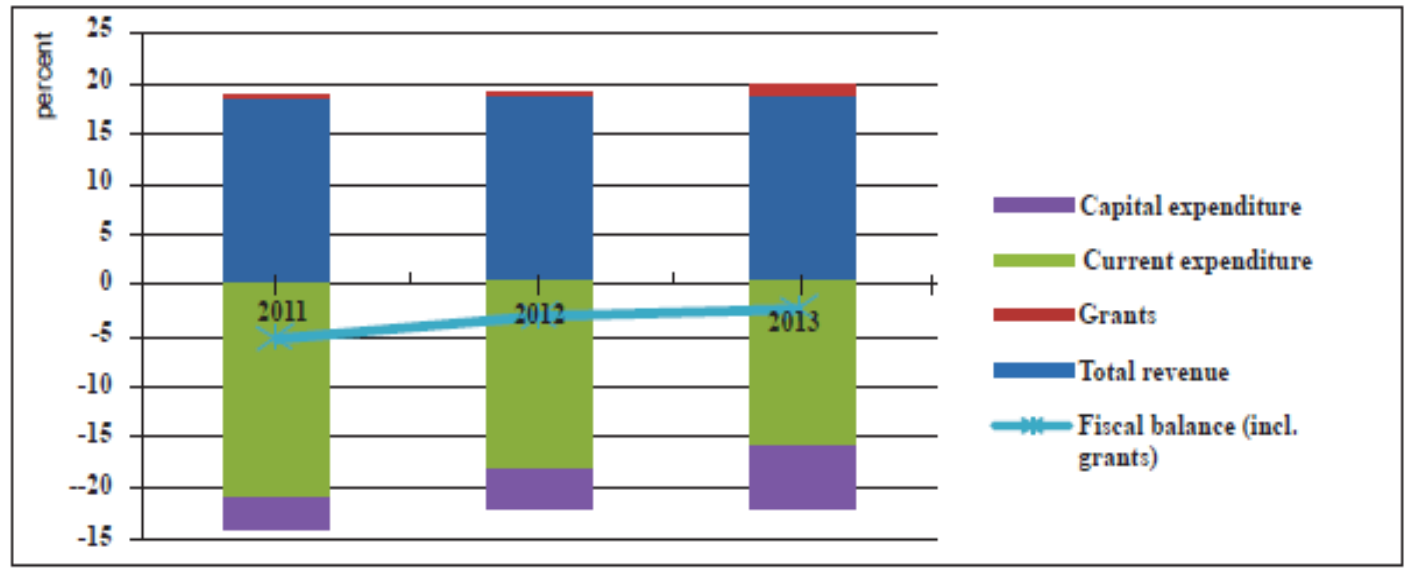

Appendix 2. Decomposition of budgets variables as a percentage of GDP, 2011-2013

Source: International Monetary Fund's (IMF).

\section{Copyrights}

Copyright for this article is retained by the author(s), with first publication rights granted to the journal.

This is an open-access article distributed under the terms and conditions of the Creative Commons Attribution license (http://creativecommons.org/licenses/by/3.0/). 